\title{
In-vivo Effect of Probiotics on Escherichia coli O157:H7 Isolated from Salad Vegetables
}

\author{
Roseline Ekiomado Uzeh ${ }^{1}$, Chinwe Amaka Okolo ${ }^{1} \&$ Bamidele Abiodun Iwalokun ${ }^{2}$ \\ ${ }^{1}$ Department of Microbiology, University of Lagos, Akoka, Lagos, Nigeria \\ ${ }^{2}$ Nigerian Institute of Medical Research, Lagos, Nigeria \\ Correspondence: Roseline Ekiomado Uzeh, Department of Microbiology, University of Lagos, Akoka, Lagos, \\ Nigeria. Tel: 234-805-121-7750. E-mail: roseline_uzeh@yahoo.com
}

\author{
Received: July 18, 2012 Accepted: August 2, 2012 Online Published: September 5, 2012 \\ doi:10.5539/jfr.v1n4p27 URL: http://dx.doi.org/10.5539/jfr.v1n4p27
}

\begin{abstract}
This study was undertaken to isolate Escherichia coli O157:H7 from salad vegetables, determine its pathogenicity and effect on the gastrointestinal tract of mice and sensitivity to probiotics; Lactobacillus lactis ATCC12315 and Lactobacillus acidophilus ATCC4356 in-vivo. Twenty seven samples made up of eight different types of salad vegetables which includes carrot, cabbage, cucumber, lettuce, peas, green pepper, green beans and spring onions were collected from different locations; markets, farm and street vendors in Lagos, Nigeria. Sampling was done between $13^{\text {th }}$ October 2009 and $17^{\text {th }}$ March 2010. In all experiments with mice the protocol for care of animal was carried out according to National Institute of Health (NIH). The mice given only E. coli $\mathrm{O} 157: \mathrm{H} 7$ developed diarrhea which led to loss of body weight and death of majority of them. On the other hand mice that were not given any microbial suspension (control), those given only probiotics, combination of E. coli O157:H7 and probiotics showed no symptom of diarrhea and there was increase in their body weight. The histopathology of the intestines of this group of mice showed that their intestines were not damaged, while those given only E. coli O157:H7 showed lymphoid hyperplasia, mucosal sloughing and inflammation (enteritis). The maintenance of good health by probiotics has again been re-emphasized.
\end{abstract}

Keywords: E. coli O157:H7, probiotics, salad vegetables, gastrointestinal tract

\section{Introduction}

Probiotics refer to a group of non-pathogenic microorganisms which when consumed in certain amount exert beneficial effects on health (Reid et al., 2003). Huang et al. (2002) demonstrated the use of a meta-analysis of randomized controlled trials to show evidence of the efficacy of lactic acid producing bacteria for both prevention and treatment of acute diarrhea in infants and young children. Beneficial activities of probiotics are usually obtained from the complex interactions of the microorganisms with the intestinal microflora and the gut epithelium of the individual (Marteau et al., 2001). The use of probiotics in animal models of inflammatory bowel disease and in diarrhea of premature infants, severe burn patients and acute and chronic colitis (Filho-Lima et al., 2000) has shown potential beneficial effects of probiotic strains. Some Lactobacillus species are used industrially for the production of yoghurt, cheese, sauerkraut, pickles; wine and other fermented foods, as well as animal feeds such as silage. The health benefits of Lactobacillus include enhancement of immune system, antimicrobial effects inhibiting intestinal and food poisoning pathogens, improvement of gut function by normalizing microflora balance and treatment of diarrhea including infantile, traveler's and antibiotic induced diarrhea (Reid et al., 2003).

Haemorrhagic colitis that characterised the first registered outbreak of E. coli O157:H7 in Oregon was described with severe abdominal cramps, little or no fever, severe bloody diarrhea and colonic mucosal oedema (Riley, 1987). This first recognized outbreak was linked to contaminated ground beef, but it is now claimed that numerous foods such as raw milk, yoghurt, lettuce, unpasteurized apple cider juice, potatoes have been implicated. Traditionally, the O157:H7 sero-type has been linked to foodborne illness outbreaks in which undercooked meats, especially ground beef, have been consumed. The CDC estimates 73,000 cases of infection with E. coli 0157:H7 and 61 deaths on average occur in the United States every year (Seto et al., 2007). The largest outbreak to date occurred in Japan in 1996, affecting over 9000 people, with contaminated radish sprouts as the possible source of infection (Michino et al., 1998). Reports of person-to-person and waterborne 
transmission have been increasing (Meng et al., 2001). E. coli O157:H7 serotypes are closely related, descended from a common ancestor, divergent in plasmid content more than chromosomal content, and are no more related to other shiga-toxin producing strains than any other randomly chosen E. coli serotype. E. coli $\mathrm{O} 55: \mathrm{H} 7$ and $E$. coli $\mathrm{O} 157: \mathrm{H} 7$ are most closely related and diverged from a common pathogenic ancestor that possessed the ability to form attaching and effacing lesions. E. coli $\mathrm{O} 157: \mathrm{H} 7$ can naturally be found in cow intestines. Therefore, any object that encounters cow feces could potentially be contaminated with E. coli O157:H7 (Whittam et al., 1988). Naturally, cows eat grass and hay, but in these massive feed lots they are fed corn as this diet is cheaper for the farmer and can mature the size of the cow much quicker than in nature. Rain water run-off from these feed lots has also made its way into our streams and lakes. Stream and lake water is regularly used to hydrate vegetable gardens which can then contaminate these vegetables (leafy greens) with E. coli (Rodrigue, 1995). The toxin requires highly specific receptors on the cells' surface in order to attach and enter the cell; species such as cattle, swine, and deer which do not carry these receptors may harbor toxigenic bacteria without any ill effect, shedding them in their feces, from which they may be spread to humans. Flesh can become contaminated during slaughter and butchering, and organisms can be thoroughly mixed into beef when it is ground into hamburger. Bacteria present on the cow's udders or on equipment may get into raw milk. Although the number of organisms required to cause disease is not known, it is suspected to be very small (Rodrigue, 1995). The consumption of contaminated meat (especially ground meat), vegetables or produce that has not been cooked sufficiently to kill E. coli $\mathrm{O} 157: \mathrm{H} 7$ can cause infection.

The aim and objectives of this research therefore are to:

- Isolate, characterize and identify E. coli O157:H7 from salad vegetables.

- Determine the pathogenicity of E. coli $\mathrm{O} 157: \mathrm{H} 7$ in the gastrointestinal tract.

- Determine the effect of probiotic organisms in the gastrointestinal tract.

- Determine the effect of the presence of probiotics associated with E. coli $\mathrm{O} 157: \mathrm{H} 7$ in the gastrointestinal tract.

\section{Materials and Methods}

\subsection{Collection of Salad Vegetables}

Twenty seven samples made up of eight different types of salad vegetables which includes carrot, cabbage, cucumber, lettuce, peas, green pepper, green beans and spring onions were collected from different locations; markets, farm and street vendors in Lagos, Nigeria. They were collected between 7-8 am on each sampling day. Sampling was done between $13^{\text {th }}$ October 2009 and $17^{\text {th }}$ March 2010, that is, for a period of 5 months.

\subsection{Isolation of Microorganisms}

From each salad vegetable $25 \mathrm{~g}$ was weighed into $225 \mathrm{ml}$ of sterile distilled water in a sterilized blender and homogenized at high speed for $3 \mathrm{~min}$. Double strength MacConkey broth medium were inoculated with each of the homogenized salad vegetables and incubated at $37^{\circ} \mathrm{C}$ for $48 \mathrm{hrs}$ for enrichment. Broth cultures were serially diluted and $0.1 \mathrm{ml}$ aliquots from $10^{-2}, 10^{-5}$ and $10^{-8}$ dilutions were spread on a set of MacConkey agar and Eosin Methylene Blue agar. The plates were incubated at $37^{\circ} \mathrm{C}$ for $24 \mathrm{hrs}$. After incubation the isolates were counted and observed for colonies resembling E. coli (rose pink colonies and metallic green sheen colonies) on MacConkey agar and Eosin Methylene Blue agar plates respectively. Pure cultures were obtained by sub-culturing.

\subsection{Identification of Isolates}

The cultural characteristics of the colonies on the plates were observed and recorded. The colonies were Gram-stained to determine their Gram reaction and biochemical tests were also done. The colonies suspected to be $E$. coli were sub-cultured onto sorbitol MacConkey agar and incubated at $37^{\circ} \mathrm{C}$ for $24 \mathrm{hrs}$. After incubation, the sorbitol fermenters appeared pinkish while the non-sorbitol fermenters appeared colourless on the plates.

\subsection{Antigenic Characteristics (Serotyping)}

The colonies that did not ferment sorbitol were then serotyped using Oxoid diagnostic kit for the identification of E. coli $\mathrm{O} 157: \mathrm{H} 7$. The test was carried out by picking the isolates with an inoculation loop and mixing it with the antisera on the tile. The mixture was swirled for some seconds and presence of agglutination confirmed the isolates to be $E$. coli $\mathrm{O} 157: \mathrm{H} 7$.

\subsection{Experimental Animals}

The animals used for the experiment were mice. A total of 31 mice were obtained from Nigerian Institute of 
Medical Research (NIMR), Yaba, and Lagos. Their stool samples were collected and tested for the presence of the pathogen E.coli $\mathrm{O} 157: \mathrm{H} 7$. On getting a negative result, the animals were certified as free from an already existence of the pathogen and were therefore fit for the experiment.

\subsection{Probiotic Cultures and Inoculation of Mice}

Pure cultures of probiotics were obtained from Federal Institute of Industrial Research (FIIRO), Oshodi, Lagos. The cultures are Lactobacillus acidophilus ATCC 4356 and Lactobacillus lactis ATCC 12315. L. acidophilus and L. lactis were inoculated into MRS broth and incubated at $37^{\circ} \mathrm{C}$ for $48 \mathrm{hrs}$ using anaerobic jar. Then they were serially diluted up to $10^{8}$-fold with sterile saline. An aliquot of $200 \mu$ l of the suspension was given orally to mice using catheter tube.

\subsection{Experimental Design}

In all experiments with mice the protocol for care of animals was carried out according to National Institute of Health (NIH). Animals were divided into six groups:

- Group A was made up of 2 mice and were not given any microbial suspension (control).

-Group B was made up of 4 mice and were given L. lactis at a concentration of $10^{8} \mathrm{cfu} / \mathrm{ml}$ on days 1, 2, 3, 4, 5 and 6.

-Group C was made up of 4 mice and were given L. acidophilus at a concentration of $10^{8} \mathrm{cfu} / \mathrm{ml}$ on days 1,2 , 3, 4, 5 and 6 .

-Group D was made up of 7 mice and were given E. coli $\mathrm{O} 157: \mathrm{H} 7$ at a concentration of $10^{3} \mathrm{cfu} / \mathrm{ml}$ on days 4 , 5 and 6

-Group E was made up of 7 mice and were given L. lactis at a concentration of $10^{8} \mathrm{cfu} / \mathrm{ml}$ on days $1,2,3$, and E. coli $\mathrm{O} 157: \mathrm{H} 7$ at a concentration of $10^{3} \mathrm{cfu} / \mathrm{ml}$ on days 4,5 and 6 .

-Group F was made up of 7 mice and were given L. acidophilus at a concentration of $10^{8} \mathrm{cfu} / \mathrm{ml}$ on days 1,2 , 3, and E. coli $\mathrm{O} 157: \mathrm{H} 7$ at a concentration of $10^{3} \mathrm{cfu} / \mathrm{ml}$ on days 4,5 and 6 .

Mice were observed for presence of diarrhea and their body weight taken each day. On day 4, 1 mouse each from groups $\mathrm{A}, \mathrm{B}$ and $\mathrm{C}$ were sacrificed under anesthesia with formalin. Their intestines were homogenized, centrifuged at $4000 \mathrm{rpm}$ for 5 mins and the supernatant was decanted, serially diluted and plated on MRS agar plates and incubated anaerobically at $37^{\circ} \mathrm{C}$ for $48 \mathrm{hrs}$. Developed colonies were counted. The intestines were also fixed with formalin for histopathology examination. On day 7, the remaining mice from groups D, E, and F were sacrificed under anesthesia with formalin. Their intestines were homogenized, centrifuged at $4000 \mathrm{rpm}$ for 5 mins and the supernatant was decanted, serially diluted, plated on MRS agar plates and sorbitol MacConkey agar plates. MRS plates were incubated anaerobically at $37^{\circ} \mathrm{C}$ for $48 \mathrm{hrs}$ while sorbitol MacConkey agar plates were incubated aerobically at $37^{\circ} \mathrm{C}$ for $24 \mathrm{hrs}$. Developed colonies were counted. The intestines were also fixed with formalin for histopathology examination.

\subsection{Gastrointestinal $\mathrm{pH}$}

Supernatants from homogenized intestines were filtered with $0.8 \mu \mathrm{m}$ pore sized filter. $\mathrm{pH}$ of filtrates were taken with a $\mathrm{pH}$ meter.

\subsection{Histopathology}

The intestines were fixed in $10 \%$ neutral buffered formalin for $6 \mathrm{hrs}$. The tissues were grossed by placing them on a board and looking for areas of interest. They were processed by cutting off a length of $5 \mathrm{~mm}$, put on already labelled cassette and transfered into an automatic tissue processor which consists of 12 beakers. From the beaker containing $10 \%$ formalin it was fixed in $70 \%$ alcohol for $2 \mathrm{hrs.} \mathrm{In} 3$ beakers containing $95 \%$ alcohol, it was fixed in the first one for $1 \mathrm{hr}$, transferred into the second one for $1 \mathrm{hr}$ and transferred into the third one for $1 \mathrm{hr}$. In 3 beakers containing absolute alcohol (100\% alcohol), it was fixed in the first one for $1 \mathrm{hr}$, transferred into the second one for $1 \mathrm{hr}$ and into the third one for $1 \mathrm{hr}$. In 2 beakers containing xylene, it was fixed in the first one for $2 \mathrm{hrs}$ and in the second one for $1 \mathrm{hr}$. In 3 beakers containing wax, it was fixed in the first one for $1 \mathrm{hr}$, transferred into the second one for $2 \mathrm{hrs}$ and into the third one for $1 \mathrm{hr}$.

Then the intestines were brought out and embedded in a mixture of molten paraffin wax and parablast, allowed to solidify on ice, mircotomed at $3-5 \mu$ on albuminized glass slides, floated on hot water bath at $56^{\circ} \mathrm{C}$, drained and dried on a hot plate, then stained using haematoxylin and eosin staining technique. Slides were viewed under the microscope. 


\section{Results}

Escherichia coli $\mathrm{O} 157: \mathrm{H} 7$ was isolated from all salad vegetables analyzed in this study. E. coli $\mathrm{O} 157: \mathrm{H} 7$ a non-sorbitol fermenting organism appeared colourless on sorbitol MacConkey agar.

\subsection{Serotyping of E. coli O157:H7 Isolates}

The result of the reaction when non-sorbitol fermenters were serotyped using Oxoid diagnostic reagent for the identification of $E$. coli $\mathrm{O} 157: \mathrm{H} 7$ indicated that agglutination was produced by them. The result of this test confirmed E. coli $\mathrm{O} 157: \mathrm{H} 7$.

\subsection{Changes in Weight of Mice}

The weight of mice in all the groups changed daily. The weight of mice in groups B, C, E, and F increased from day 1 to 7 , while those in group D increased up to day 3, then decreased afterwards (Figure 1).

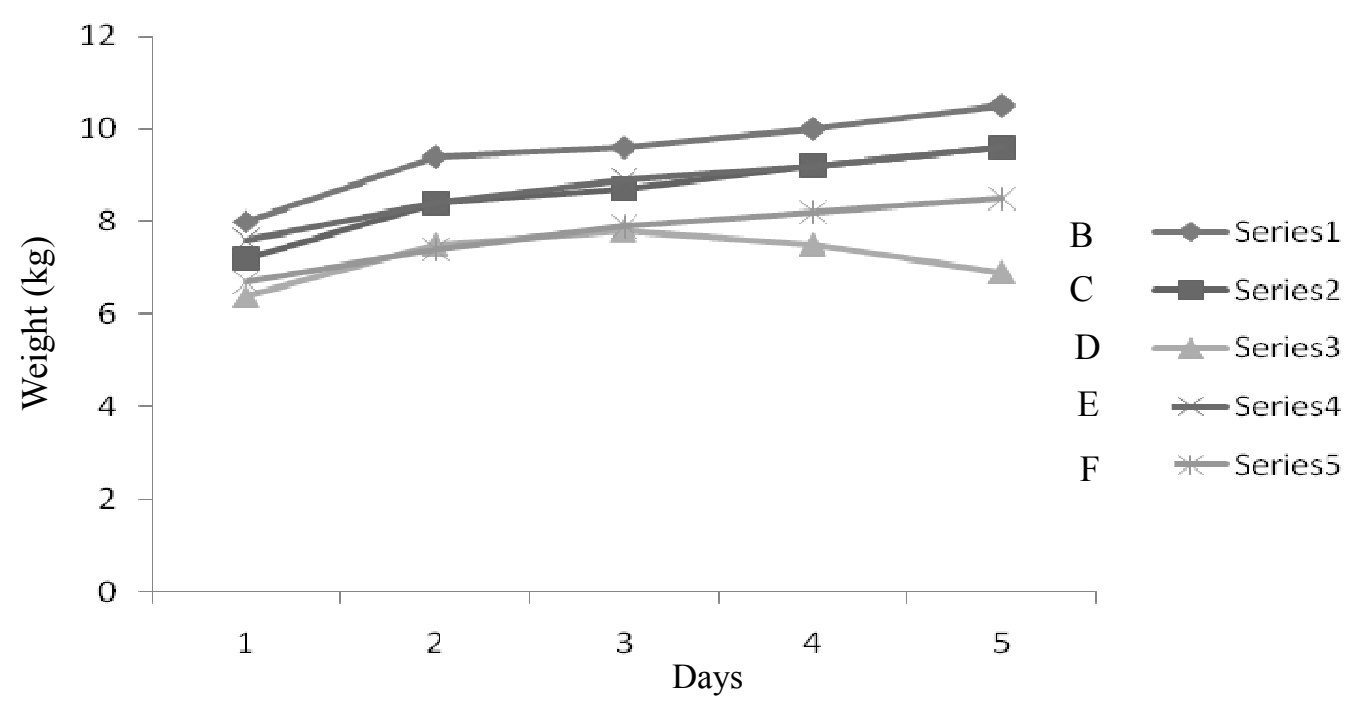

Figure 1. Change in weight of mice given Lactobacillus lactis (B), Lactobacillus acidophilus (C), Escherichia coli $\mathrm{O} 157: \mathrm{H} 7$ (D), L. lactis + E. coli $\mathrm{O} 157: \mathrm{H} 7$ (E), L. acidophilus + E. coli $\mathrm{O} 157: \mathrm{H} 7$ (F)

\subsection{Clinical Symptoms}

Some of the infected mice showed no signs of diarrhea while some did. On day 5, decrease in weight and softening of stool was observed on 5 mice (71.4\%) in group D. On day 6, the stooling observed on the 5 mice worsened and they became less active, while the remaining 2 mice $(28.6 \%)$ in the same group developed slight diarrhea and loss of weight. On day 7, 5 of the mice in group D died (severe diarrhea) but no bloody diarrhea was observed. The mice in groups $\mathrm{E}$ and $\mathrm{F}$ did not show sign of diarrhea, they remained active till day 7 (Table 1). Viable microbial counts in the gastrointestinal tracts of mice increased dramatically. Lactobacillus strains in groups B and C increased more than in groups $\mathrm{E}$ and F. E. coli $\mathrm{O} 157: \mathrm{H} 7$ in group D also increased (Figures 2-4).

Table 1. Severity of diarrhea in mice infected with E. coli $\mathrm{O} 157: \mathrm{H} 7$ by day 7

\begin{tabular}{lllllll}
\hline \multirow{2}{*}{$\begin{array}{l}\text { Diarrhea } \\
\text { Severity }\end{array}$} & \multicolumn{5}{c}{ Number of mice/total (\%) } \\
\cline { 2 - 7 } & Group A & Group B & Group C & Group D & Group E & Group F \\
\hline No diarrrhea & $2 / 2(100.0)$ & $4 / 4(100.0)$ & $4 / 4(100.0)$ & $0 / 7(0.0)$ & $7 / 7(100.0)$ & $7 / 7(100.0)$ \\
Slight diarrhea & $0 / 2(0.0)$ & $0 / 4(0.0)$ & $0 / 4(0.0)$ & $2 / 7(28.6)$ & $0 / 7(0.0)$ & $0 / 7(0.0)$ \\
Severe diarrhea & $0 / 2(0.0)$ & $0 / 4(0.0)$ & $0 / 4(0.0)$ & $5 / 7(71.4)$ & $0 / 7(0.0)$ & $0 / 7(0.0)$ \\
\hline
\end{tabular}




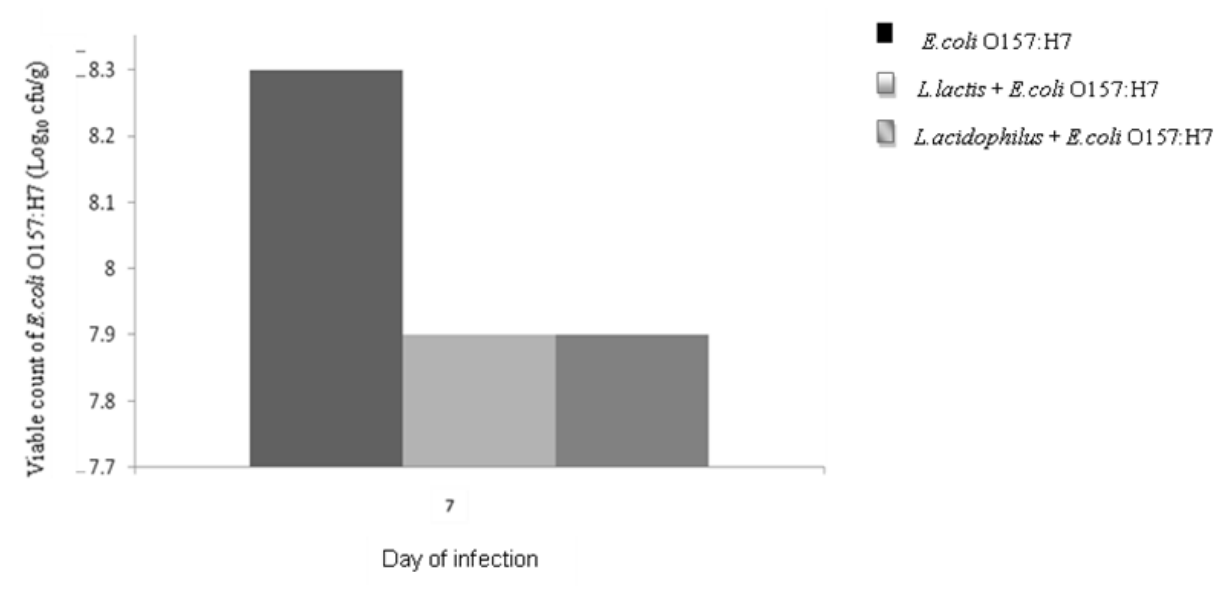

Figure 2. Colonization and distribution of E. coli $\mathrm{O} 157: \mathrm{H} 7$, L. lactis + E. coli $\mathrm{O} 157: \mathrm{H} 7$ and L. acidophilus + E. coli $\mathrm{O} 157: \mathrm{H} 7$ in the gastrointestinal tract of mice

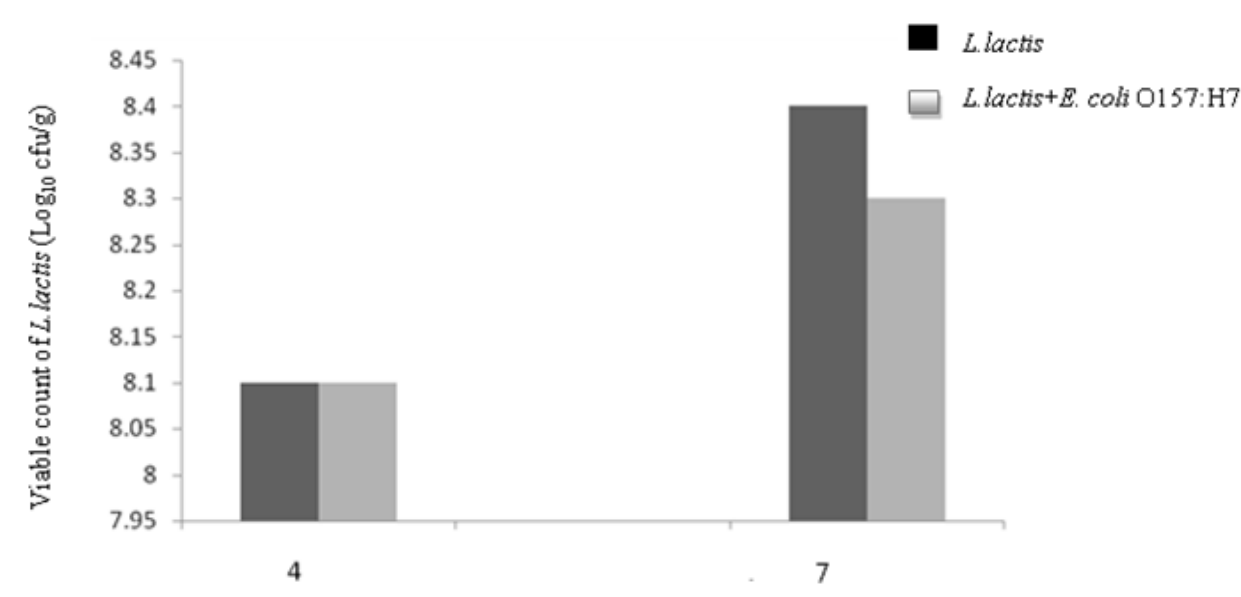

Days of infection

Figure 3. Colonization and distribution of L. lactis and L. lactis + E. coli $\mathrm{O} 157: \mathrm{H} 7$ in thr gastrointestinal tract of mice

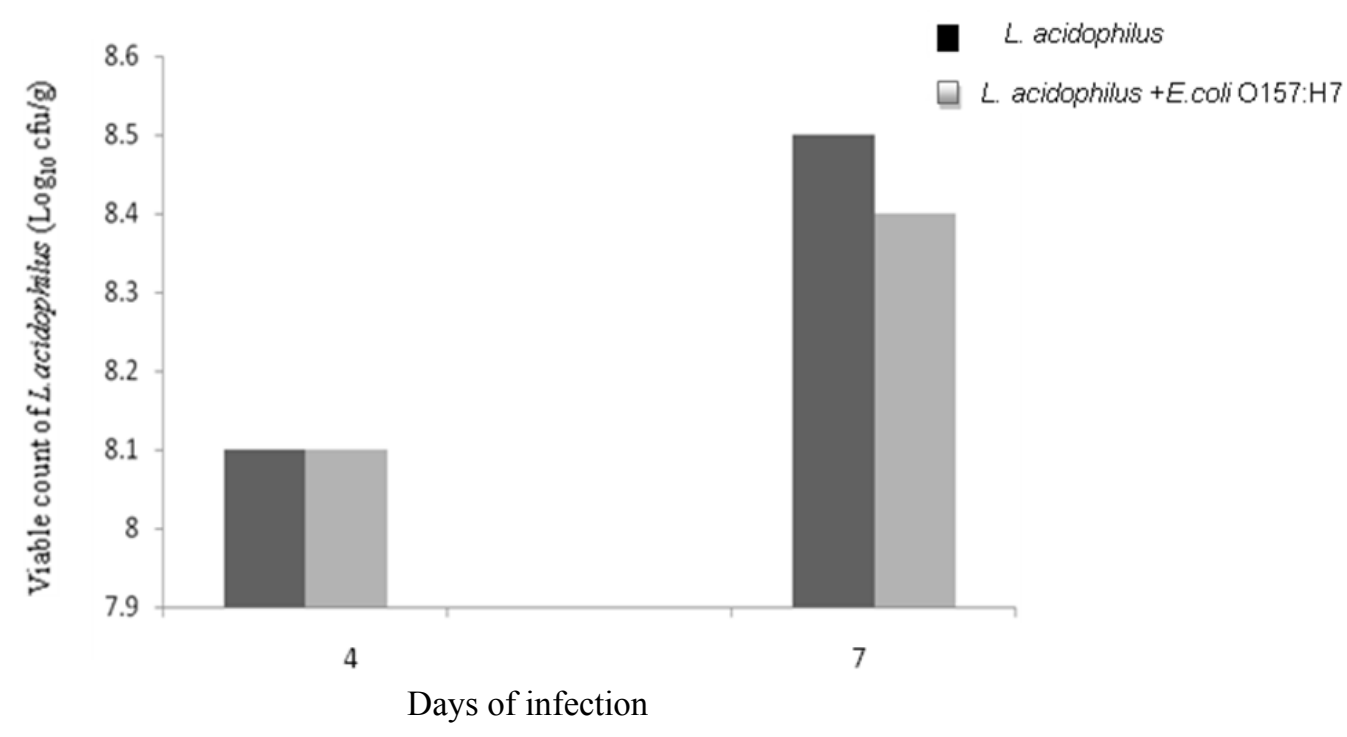

Figure 4. Colonization and distribution of L. acidophilus and L. acidophilus + E. coli $\mathrm{O} 157: \mathrm{H} 7$ in the gastrointestinal tract of mice 


\section{$3.4 \mathrm{pH}$ of Gastrointestinal Tract of Mice}

There was no difference in the $\mathrm{pH}$ of the gastrointestinal tract of mice in various groups on day 7 even after infection was observed in some of the groups. The $\mathrm{pH}$ was approximately 6.6 .

\subsection{Histopathology}

From the histopathological results, intestine of mice from group A(control) was normal. Intestines in groups B, given L. lactis, C, given L. acidophilus, E, given L. lactis + E. coli $\mathrm{O} 157: \mathrm{H} 7, \mathrm{~F}$, given L. acidophilus + E. coli O157:H7 were also normal (Figure 5). That of group D fed with only E. coli O157:H7 showed lymphoid hyperplasia, mucosal sloughing and inflammation (enteritis) (Figures 6 and 7).

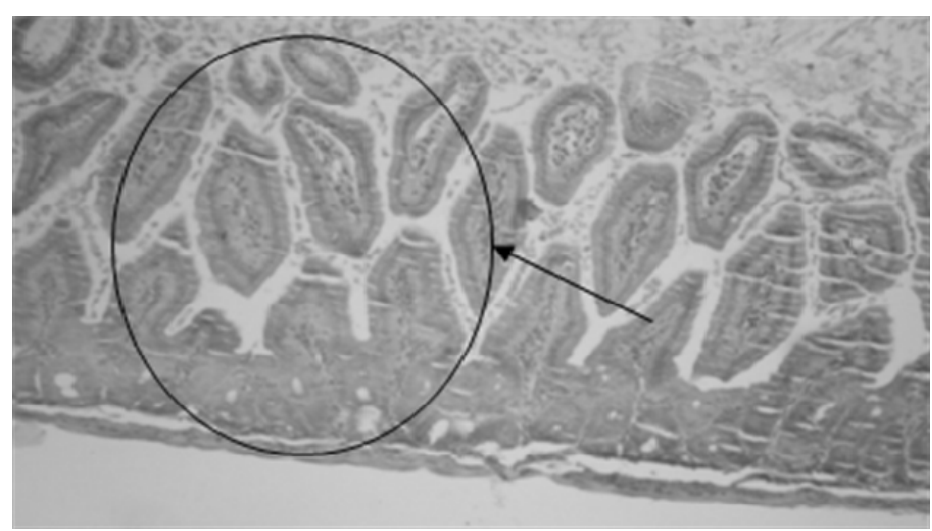

Figure 5. Normal intestine of mice

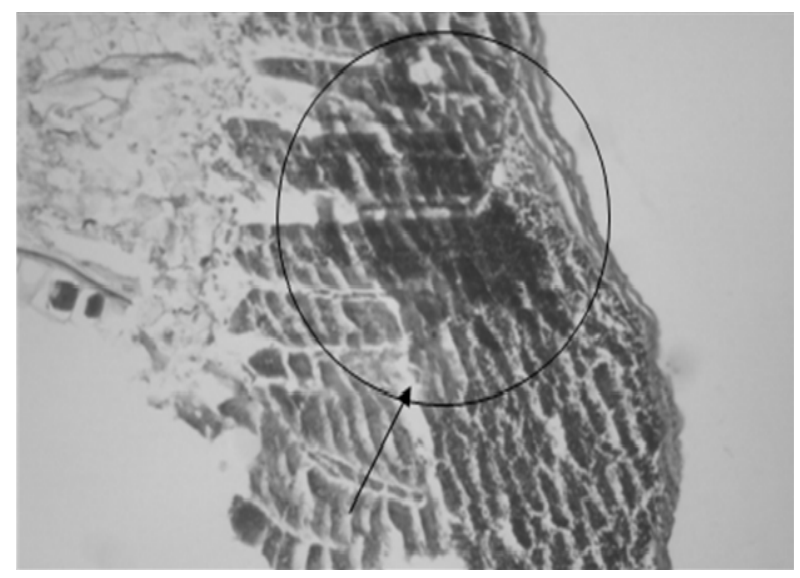

Figure 6. Intestine of mice showing lymphoid hyperplasia

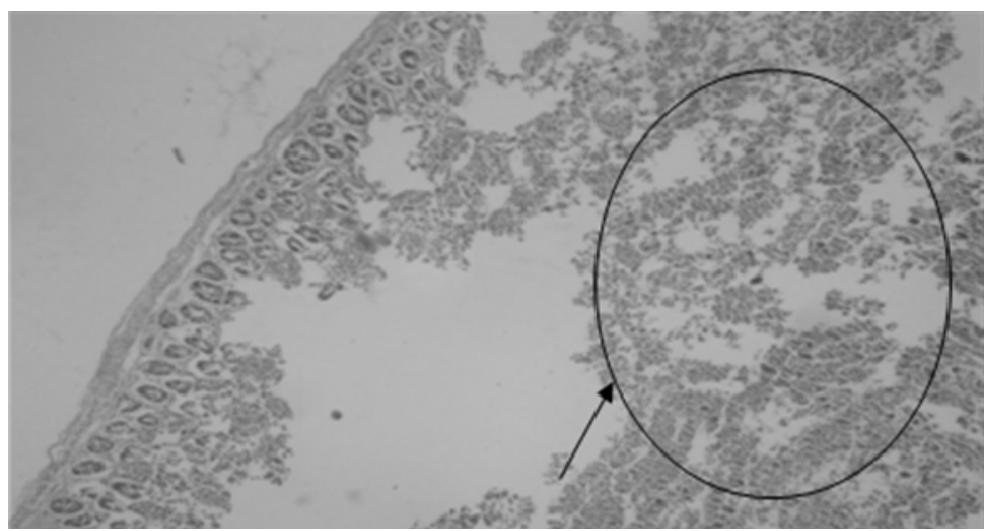

Figure 7. Intestine of mice showing mucosal sloughing, inflammation (enteritis) 


\section{Discussion}

The isolation of E. coli $\mathrm{O} 157: \mathrm{H} 7$ from salad vegetables is of public health significance because this organism is a known food pathogen and salad vegetables are consumed with minimal processing and in most cases without heating. Cattle have been recognized as the principal reservoir of the microorganism in water and food borne $E$. coli O157:H7 outbreaks and sporadic infections (Smith et al., 2003). Outbreaks of diseases caused by pathogenic strains of $E$. coli have been described in many parts of the world. Animal faeces can easily be washed by rain water into salad vegetable farms or even into rivers or ground water which may be used to water salad vegetable farms. Some farms may even be located close to a septic tank or broken sewer line. Contamination may also be caused by animals and humans defecating in vegetable farms. The organism can survive in the environment for months, making the risk of infection in contaminated areas even higher (Crump et al., 2002).

The diarrhea observed in mice in group D may have been caused by E. coli $\mathrm{O} 157: \mathrm{H} 7$ which was used to infect the mice because there was no diarrhea in the control mice without E. coli O157:H7. Diarrhea was also not observed in mice in groups B, C, E and F. This may also be because of the absence of the organism in mice in groups $\mathrm{B}$ and $\mathrm{C}$ which were given only probiotic organisms. Although E. coli $\mathrm{O} 157: \mathrm{H} 7$ was present in mice in groups $\mathrm{E}$ and $\mathrm{F}$, they were also given probiotic organisms which may have prevented occurrence of diarrhea in these groups. Probiotic Lactobacillus strains have been shown to protect against infection by pathogens including E. coli O157:H7 (Nomoto et al., 1992). Lactobacillus is a genus of Gram-positive facultative anaerobic or microaerophilic bacteria. They are a major part of the lactic acid bacteria group, named as such because most of its members convert lactose and other sugars to lactic acid (Dicks et al., 2000). The production of lactic acid makes its environment acidic, which inhibits the growth of some harmful bacteria. The probiotic bacterium Clostridium butyricum MIYAIRI strain 588 have been reported to have preventive and therapeutic effects on Enterohemorrhagic Escherichia coli O157:H7 infection in gnotobiotic mice (Motomichi et al., 2004).

The histopathology of mice also revealed that the intestines of mice in all the groups except group D had normal intestines. The abnormalities (lymphoid hyperplasia, mucosal sloughing and inflammation) observed in mice in group D may have been due to the action of $E$. coli $\mathrm{O} 157: \mathrm{H} 7$. The probiotics may have equally prevented these abnormalities in mice in groups E and F. Thus the probiotic bacteria Lactobacillus lactis ATCC 12315 and Lactobacillus acidophilus ATCC 4356 helped to maintain good health in mice by their preventive and therapeutic effect on E. coli $\mathrm{O} 157: \mathrm{H} 7$ infection in the mice.

\section{Conclusion}

Escherichia coli $\mathrm{O} 157: \mathrm{H7}$ was isolated from all salad vegetables. The isolate was pathogenic and caused diarrhea in mice. It also resulted in lymphoid hyperplasia, mucosal sloughing and inflammation (entiritis) in the intestines of mice. However, the probiotic organisms exerted therapeutic effect on the pathogen.

\section{References}

Crump, J., Sulka, A., \& Langer, A. (2002). An outbreak of Escherichia coli O157:H7 infection among visitors to a dairy farm. $N$ Engl J Med., 347, 555-560. http://dx.doi.org/10.1056/NEJMoa020524

Dicks, L. M. T., Silvester, M., Lawson, P. A., \& Collins, M. D. (2000). Lactobacillus fornicalis isolated from the posterior fornix of the human vagina. Intern $J$ Systemat Evolut Microbiol., 50, 1253-8. http://dx.doi.org/10.1099/00207713-50-3-1253

Filho-Lima, J. V. M., Viera, E. C., \& Nicole, J. R. (2000). Antagonistic effect of Lactobacillus acidophilus, Streptococcus boulardii and Escherichia coli combinations against experimental infections with Shigella flexneri and Salmonella typhimurium in gnotobiotic mice. $J$ Appl Microbiol., 88, 365-370. http://dx.doi.org/10.1046/j.1365-2672.2000.00973.x

Huang, J. S., Bousvaros, A., Lee, J. W., Diaz, A., \& Davidson, E. J. (2002). Efficacy of probiotic use in acute diarrheain children. A meta-analysis. Dig Dis Sci., 47, 2625-2634. http://dx.doi.org/10.1023/A:1020501202369

Marteau, P. R., de Vrese, M., Cellier, C. J., \& Schrezenmeir, J. (2001). Protection from gastrointestinal diseases with the use of probiotics. Am J Clin Nutr., 73, 4305-4365.

Meng, J., Doyle, M. P., Zhao, T., \& Zhao, S. (2001). Enterohemorrhagic Escherichia coli. In: Food Microbiology, Fundamentals and Frontiers, Doyle, M. P., Beuchat L. R., Montville T. J., Eds, 2nd edn., ASM Press, Washington, D. C., pp. 193-213.

Michino, H., Araki, K., Minami, S., Nakayama, T., Ejima, Y., Hiroe, K., ... Sakai, N. (1998). Recent outbreaks of infections caused by Escherichia coli O157:H7 in Japan. In: Escherichia coli O157:H7 and Other Shiga 
Toxin-Producing E. coli Strains. Kaper J. B., O’Brien A., Eds, ASM Press, Washington, D.C., pp. 73-81.

Motomichi, T., Haruhiko, T., Hiroyuki, Y., Takako, O., Akio, K., \& Shigeru, K. (2004). The effect of probiotic treatment with Clostridium butyricum on enterohemorrhagic Escherichia coli O157:H7 infection in mice. Immun Med Micro., 41, 219-226. http://dx.doi.org/10.1016/j.femsim.2004.03.010

Nomoto, K., Yokokura, T., Mitsuyama, M., \& Yoshikai, Y. (1992). Prevention of indigenous infection of mice with Escherichia coli by nonspecific immunostimulation Antimicrob Agents Chemother, 36, 361-367. http://dx.doi.org/10.1128/AAC.36.2.361

Reid, G., Jass, J., Sebulsky, M. T., \& McCormick, J. K. (2003). Potential uses of probiotics in clinical practice. Clin Microbiol Rev., 16, 658-672. http://dx.doi.org/10.1128/CMR.16.4.658-672.2003

Riley, L. W. (1987). The epidemiological, clinical, and microbiological features of hemorrhagic colitis. Ann Rev Microbiol, 41, 383-407. http://dx.doi.org/10.1146/annurev.mi.41.100187.002123

Rodrigue, D. C., Mast, E. E., Greene, K. D., Davis, J. P., Hutchinson, M. A., Wells, J. G., .. Griffin, P. M. (1995). A university outbreak of Escherichia coli $\mathrm{O} 157: \mathrm{H} 7$ infections associated with roast beef and an unusually benign clinical course. J Infect Dis., 172, 1122-1125. http://dx.doi.org/10.1093/infdis/172.4.1122

Seto, E. Y. W., Soller, J. A., \& Jr. Colford, J. M. (2007). Strategies to reduce person-to-person transmission during widespread Escherichia coli O157:H7 outbreak. Emerg. Infect. Dis., 13(6), 860-866. http://dx.doi.org/10.3201/eid1306.061264

Smith, S. I., Aboaba, O. O., Odeigha, P., Shodipo, K., Adeye, S. A., \& Ibrahim, A. (2003). Plasmid profile of Escherichia coli O157:H7 from apparently healthy animals. Afri J Biotech, 2(9), 322-324.

Whittam, T. S., Wachsmuth, I. K., \& Wilson, R. A. (1988). Genetic evidence of clonal descent of Escherichia coli $\mathrm{O} 157: \mathrm{H} 7$ associated with hemorrhagic colitis and hemolytic uremic syndrome. J Infect Dis., 157(6), 1124-33. http://dx.doi.org/10.1093/infdis/157.6.1124 